\title{
MAJOR AIR POLLUTANTS AND THEIR EFFECTS
}

\author{
H. S. Doreswamy* and S. R. Sudheendra**
}

\begin{abstract}
Air pollution is the introduction of chemical, particulate matter or biological materials that cause harm or discomfort to humans or other living organisms, or damages the natural environment, into the atmosphere.

The atmosphere is the thin layer of gases that surrounds the earth surfaces. Recently, environmental problems have been local and minor because of the earth's own ability to absorb and purify minor quantities of pollutants. The industrialization, introduction of more number of vehicles, and the explosion of the population, are contributing toward the growing air pollution problem.

Knowing of major air pollutants and their effects are very important to global world.
\end{abstract}

* Department of Mathematics, M.S. Engineering College, Bangalore, hsdoreswamy@rediffmail.com

** Administrative Management College, Bangalore, surakshasrs@yahoo.com 


\section{Major Air Pollutants}

The following are the major identified ambient air pollutants:-

\begin{tabular}{|l|l|l|l|}
\hline POLLUTANTS & SYMBOL & FORM & \multicolumn{1}{|c|}{ TYPE } \\
\hline Particulate Matters & $\begin{array}{l}\text { TSP(Total } \\
\text { Suspended } \\
\text { Particulates) }\end{array}$ & Particulate & Primary \& Secondary \\
Carbon Monoxides & $\mathrm{CO}$ & Gaseous & Primary \\
Nitrogen Oxides & $\mathrm{NOX}$ & Gaseous & Primary \& Secondary \\
Sulphur dioxides & $\mathrm{SO} 2$ & Gaseous & Primary \\
Hydrocarbons & $\mathrm{HC}$ & Gaseous & Primary \\
Ozone & $\mathrm{O} 3$ & Gaseous & Secondary \\
Lead & $\mathrm{Pb}$ & Particulate & Primary \\
\hline
\end{tabular}

The following gives the explanation of the above tabulated pollutants:-

\section{Particulate Matter}

Air born small solid and liquid droplets are known as Particulates. Solid particles generated by handling, crushing, grinding, spraying and other operations are known as Particulate Matter. These particulate matters are generated from burning coal in power and industrial sector, burning petrol and diesel in vehicles, construction and agricultural activities. Particulate air pollution is a complex mixture of small and large particles of varying origin and chemical composition. Some of the particulate pollutants are lead, asbestos, copper and zinc etc. The particulate matters stay in the atmosphere from a few seconds to several months depending on their size, density, settling velocity and turbulence. Particles of size 2.5-100 microns in diameter is usually comprised of smoke and dust from industrial processes, agriculture, construction, plant pollen, road traffic and other natural sources. Particles of size less than 2.5 microns in diameter generally come from combustion of fossil fuels. These particles include soot from vehicle exhaust which is often coated with various chemical contaminants, fine sulphate, and nitrate aerosols. 
The effects caused by particulate matter are reduction in visibility, change in urban climatological characteristic and change in chemical characteristics of precipitation. The health effects of particulates are strongly linked to particle size. Small and light particles will be in suspension, whereas bigger sized particles settle by their own weight. Small particles, such as those from fossil fuel combustion are likely to be most dangerous, because they can be inhaled deeply into the lungs, settling in areas where the body's natural clearance mechanisms cannot remove them. The constituents in small particulates also terid to be more chemically active and may be acidic as well and therefore leading to more damage. Larger particles can be stopped in the nose and upper lungs by the body's natural defenses. Exposure to particulate pollution can cause wheezing and other symptoms in people with asthama.

\section{Carbon Monoxide (CO)}

Carbon monoxide is a colorless, odorless, poisonous gas formed during the incomplete combustion of fuels from automobiles or industries. If the combustion of fuels from automobiles or industries is complete, then the product will be carbon dioxide which is not generally considered as an air pollutant because it is not harmful to humans and is required for the photosynthesis. However the presence of excess carbon dioxide in the earth's atmosphere is believed to cause global warming nowadays. Coal mining and oxidation of methane also produces $\mathrm{CO}$. Formation of $\mathrm{CO}$ depends upon factors like air-fuel ratio and ignition temperature. $\mathrm{CO}$ level in urban area ranges from 5 to $50 \mathrm{ppm}$. Carbon monoxide is very harmful to those persons who are exposed to the level of $100 \mathrm{ppm}$. The $\mathrm{CO}$ is fatal at higher concentration of $1000 \mathrm{ppm}$. Carbon monoxide interferes with the bloods ability to carry oxygen to the brain, heart and other tissues, and it is particularly dangerous for people with existing heart disease, and in unborn or new born children. When a person inhales air polluted with carbon monoxide in the lungs the hemoglobin in the blood will be readily combining with the carbon monoxide rather than the oxygen and forms Carboxy Hemoglobin. This is because of the fact that hemoglobin has got around 200 times more affinity towards carbon monoxide than oxygen. Hence when the air is polluted with carbon monoxide, human blood is likely to be deprived of oxygen and this could lead to coma and death. In mild dosages the symptoms include headache, tiredness and also reduced mental activity. Soil, vegetation, sea-water and micro-organisms remove $\mathrm{CO}$ from the atmosphere.

\section{Nitrogen Oxides (NOx)}

The different forms of Nitrogen Oxides (NOx) are Nitrous Oxide $\left(\mathrm{N}_{2} \mathrm{O}\right)$, Nitric Oxide $(\mathrm{NO})$ and Nitrogen dioxide $\left(\mathrm{NO}_{2}\right)$. These oxides of nitrogen compounds contribute to ozone formation, and are a health problem themselves. Nitrogen 
oxide is a reddish brown irritating gas, released from fuel combustion in industrial plants and automobiles. They are generally found in measurable concentration even in unpolluted atmosphere. Out of these $\mathrm{NO}$ and $\mathrm{NO}_{2}$ are major pollutants. $\mathrm{NO}_{x}$ also changes in the atmosphere to form acidic particles and liquid nitric acid. They are also produced due to the action of cosmic rays in upper atmosphere (stratosphere). About $95 \%$ of $\mathrm{NO}_{x}$ is produced as $\mathrm{NO}$ and remaining $5 \%$ as $\mathrm{NO}_{2}$. $\mathrm{NO}$ is responsible for photochemical reactions which form PAN (peroxy-acetylnitrate), $\mathrm{O}_{3}$, carbonyl compounds etc. $\mathrm{NO}_{2}$ is the chief constituent of photochemical smog. High levels of $\mathrm{NO}_{2}$ exposure can cause people coughs and can make them short of breath; these people have higher chances of getting respiratory infections. $\mathrm{NO}_{x}$ reacts with moisture and then forms $\mathrm{HNO}_{3}$ (acid mist) falls on the ground as acid rain. Acid rain can hurt plants \& animals and can make lakes dangerous for the aquatic organisms living in it.

\section{Sulphur Dioxide $\left(\mathrm{SO}_{2}\right)$}

Sulphur dioxide is a colorless and pungent gas obtained from the coal burning process, containing $10 \%$ to $15 \%$ of sulphur as an impurity in coal. Burning of fossil fuel in domestic, industrial, power plants and furnaces releases around $75 \%$ of $\mathrm{SO}_{2}$ in atmosphere, other $25 \%$ is from petroleum refineries and non-ferrous smelters. $\mathrm{SO}_{2}$ combines with water to form sulphuric acid which is also harmful to life and materials. $\mathrm{SO}_{2}$ constricts air passages, making it a problem for people with asthama and for young children. Even brief exposure to relatively low level of $\mathrm{SO}_{2}$ can cause difficulty in breathing.

\section{Hydrocarbons $(\mathrm{HC})$}

Hydrocarbons are composed of hydrogen and carbon. $\mathrm{HC}$ are in gaseous form at normal atmospheric conditions. The main sources are motor vehicles which emits by evaporation of petrol through carburetors, crankcase etc. evaporation from two and three wheels accounts for $65 \%$ of the total $\mathrm{HC}^{\prime}$ 's and the rest from unburnt fuel. They cause health hazard due to the formation of photochemical reactions. $\mathrm{HC}^{\prime} \mathrm{s}$ have carcinogenic effect on lungs of human. They also cause eye irritations, respiratory distress, nose and throat irritations.

\section{Ozone $\left(\mathrm{O}_{3}\right)$}

Ozone is formed in the atmosphere through the chemical reaction involving $\mathrm{NO}_{2}$ $\mathrm{SO}_{2}$ and aldehydes on absorption of UV-radiation. Ozone is gaseous in nature. In the stratosphere a protective layer of ozone is found, while pollutant ozone occurs in the troposphere.

$\mathrm{NO}_{2}+\mathrm{HC}=$ Ozone 
Ozone is the main constituent of photochemical smog. Increase in $\mathrm{O}_{3}$ concentration near the earth surface has adverse effect on human health, reduces crop yields significantly. $\mathrm{O}_{3}$ damages tomato, bean, tobacco and other plants. $\mathrm{O}_{3}$ produces visible damage to leaves. Ozone also reacts with dyes, cotton, nylon etc, and damages them. Occasionally special weather conditions draw ozone-rich air from the upper atmosphere down to the earth along leading edges of cold fronts.

\section{Lead $(\mathrm{Pb})$}

Lead is a grey metal and fairly abundant on earth. Lead is derived from orebearing minerals. Lead is largely emitted into atmosphere in a gaseous state through emissions from vehicles using fuel that contains lead. Lead compound are added to petrol as anti-knocking agent. Lead inhalation causes reduced hemoglobin formation, and leads to anemia. Other effect includes liver and kidney infections in humans.

\section{Harmful effects of air pollution}

Air pollution affects health of the human beings and animals, agricultural yield, materials, properties and reduction in visibility in the atmosphere. Extent of damage depends upon the nature of pollutant, concentration and duration of exposure. Atmospheric conditions like temperature and humidity also play a prominent role. The health effects of air pollutants are classified as short term effects and long term effects.

Air pollution causes damage mainly to the respiratory tract. The short effects include irritation of eyes, nose, throat, skin and also upper respiratory infections such as pneumonia and bronchitis, allergic reactions and nausea. Long term health effects are lung cancer, chronic respiratory disease and damage caused to liver, nervous system, kidneys and brain. Some chemicals also enter the nervous system while some damage heart, kidneys and liver. All chemicals have a threshold limit value beyond which the chemical will be toxic to human life.

Main global air pollution problems are ozone depletion, aerosol scattering, green house effects, acid rain, photochemical smog, long range transportation of air pollutants and heat inlands. Air pollution can cause economic loss by damaging the property like corrosion of metals, eroding or soiling of building surfaces, rubber cracking, fading of paints etc. air pollutants have a direct or indirect effect on environmental factors like temperature, sunlight and humidity also play a crucial role in reducing the strength, quality, utility and value of any material. 


\section{Conclusion}

The below table summarizes the effects of air pollutants:-

\begin{tabular}{|c|c|c|}
\hline POLLUTANTS & SOURCES & EFFECTS \\
\hline Particulate Matters & $\begin{array}{l}\text { Burning of coal, } \\
\text { manufacturing process }\end{array}$ & $\begin{array}{l}\text { Reduction in visibility } \\
\text { and asthama. }\end{array}$ \\
\hline Carbon Monoxides & $\begin{array}{l}\text { Incomplete combustion } \\
\text { of fuels from automobiles } \\
\text { or industries }\end{array}$ & $\begin{array}{l}\text { Interferes with the } \\
\text { bloods ability to carry } \\
\text { oxygen to the brain, } \\
\text { heart and other tissues. }\end{array}$ \\
\hline Nitrogen Oxides & $\begin{array}{l}\text { Released from fuel } \\
\text { combustion in industrial } \\
\text { plants and automobiles }\end{array}$ & $\begin{array}{l}\text { Photochemical smog } \\
\text { and acid rain } \\
\text { formation. }\end{array}$ \\
\hline Sulphur dioxides & Coal and oil combustion & $\begin{array}{l}\text { Constricts air passages } \\
\text { leading to breathing } \\
\text { problems. }\end{array}$ \\
\hline Hydrocarbons & $\begin{array}{l}\text { Burning of petroleum } \\
\text { products }\end{array}$ & $\begin{array}{l}\text { Causes eye irritations, } \\
\text { respiratory distress, } \\
\text { nose and throat } \\
\text { irritations. }\end{array}$ \\
\hline Ozone & $\begin{array}{l}\mathrm{NO}_{2} \mathrm{SO}_{2} \text { and } \\
\text { aldehydes on absorption } \\
\text { of UV-radiation }\end{array}$ & Reduces crop yields. \\
\hline Lead & Burning of leaded petrol & $\begin{array}{l}\text { Causes reduced } \\
\text { hemoglobin formation, } \\
\text { and leads to anemia. }\end{array}$ \\
\hline
\end{tabular}




\section{References}

BENNY JOSEPH, 2006, Environmental Studies, Tata Mcgraw-hill publishing company limited, New Delhi.

B.K.SHARMA and H.KAUL, 1997, An Introduction to Environmental Pollution, Goel publishing House, Meerut.

BRIDGMAN, H.A.1990, Global Air Pollution, Blhaven Press, London.

FINLAYSON-PITTS B.J and PITTS J.N., Jr. 1986, Atmospheric Chemistry, John Wiley, New York.

GILBERT.M.MASTERS, Introduction to Environmental Engineering and Science, $2^{\text {nd }}$ Edition, Prentice Hall.

P. VENUGOPALA RAO, 2006, Principles of Environment Science and Engineering, prentice-Hall of India private limited, New Delhi.

RAO.M.N and H.V.N.RAO, Air Pollution, Tata Mcgraw-hill publishing company limited, New Delhi.

S.M.PRAKASH, Environmental Studies, Elite Publishers, Mangalore.

SPEDDING.D.J, 1974, Air Pollution, Oxford University Press, London. 